\title{
Морфологічна характеристика легенів тварин з експериментальним перитонітом
}

\section{І. Я. Дзюбановський ${ }^{1}$, Б. М. Вервега ${ }^{2}$, С. Р. Підручна ${ }^{1}$, Н. А. Мельник ${ }^{1}$ \\ ${ }^{1}$ Тернопільський національний медичний університет імені І. Я. Горбачевського, ЛЬвівський національний медичний університет імені Данила Галицького \\ Morphologic characteristic of the lungs in the patients, suffering experimental peritonitis}

\author{
I. Ya. Dzubanovsky ${ }^{1}$, B. M. Vervega ${ }^{2}$, S. R. Pidruchna ${ }^{1}$, N. A. Melnyk ${ }^{1}$ \\ ${ }^{1}$ I. Gorbachevskyi Ternopil National Medical University, \\ ${ }^{2}$ Danylo Galytskyi Lviv National Medical University
}

\section{Реферат}

Мета. Вивчити та оцінити морфологічні зміни в легенях тварин з експериментальним гострим поширеним перитонітом. Матеріали і методи. У цьому дослідженні використано 32 білих щури. Гострий перитоніт моделювали шляхом введення 0,5 мл 10\% розчину захопленої фекальної суспензії в черевну порожнину досліджуваних тварин. Строки спостереження: 1-ша, 3-тя, 7-ма доби від початку моделювання перитоніту. Для гістологічного дослідження брали тканину легенів. Отримані шматочки органа фіксували в 10\% розчині нейтрального формаліну, а потім фарбували гематоксиліном і еозином.

Результати. Упродовж усього спостереження посилювалася ексудативно-запальна реакція судин, виникали дистелектаз, ділянки спадання та емфізематозного розширення альвеол, а також розширення та повнокров'я судин. Стінка бронхів потовщувалась переважно за рахунок клітинних інфільтратів, просвіти бронхіол були вільними від ексудату та клітинних елементів.

Висновки. Під час гістологічного дослідження тканини легенів тварин із змодельованим гострим поширеним перитонітом у порівнянні з інтактними щурами на 1-шу добу експерименту було виявлено ділянки спадання та емфізематозного розширення альвеол. На 3-тю добу більшість судин мала широкі повнокровні просвіти, відбувався еритродіапедез як у периваскулярні простори, так і в просвіт окремих альвеол. На 7-му добу спостерігали значне розширення вен та кровонаповнення артерій.

Ключові слова: гострий поширений перитоніт; легені; морфологічні зміни.

Abstract

Objective. To study and estimate the morphological changes in the lungs of laboratory animals with experimental acute extended peritonitis.

Materials and methods. In this investigation were applied on 32 white laboratory rats. An acute peritonitis was simulated, using injection of $0.5 \mathrm{ml}$ of a $10 \%$ solution of the fecal suspension probed into abdominal cavity of laboratory animals. The observation terms were implemented on the first, third and the seventh day from the beginning of the peritonitis simulation. Pulmonary tissue was taken for histological investigation. The organ pieces obtained were fixated in $10 \%$ solution of neutral formalin and then colored using hematoxylin and eosin.

Results. Distelectasis, the sites of collapse and emphysematous dilation of alveoli, have had occurred during all observation period of the exudative-inflammatory vascular reaction. The bronchi wall have thickened predominantly due to cellular infiltrates, the bronchioles lumens were free of exudate and cellular elements.

Conclusion. The sites of collapsing and emphysematous dilation of alveoli were revealed during histological investigation of pulmonary tissues in experimental animals with simulated acute extended peritonitis, comparing with intact rats in the first day of the experiment. On the third day the majority of vessels have had wide lumens filled with the blood, and erythrodiapedesis occurred into perivascular compartments and into lumens of a separate alveoli. On the $7^{\text {th }}$ day significant dilation of the veins and the arteries filling with the blood was noted.

Keywords: acute extended peritonitis; lungs; morphological changes.

Гострий поширений перитоніт (ГПП) залишається актуальною проблемою через високу смертність, обумовлену, очевидно, комплексом тяжких патофізіологічних реакцій з порушенням функціонування всіх систем гомеостазу [1 - 4]. Більшість авторів вважають, що першим органом, який зазнає ураження за наявності ГПП, є легені, а функціональна недостатність інших органів та сис- тем у 83\% спостережень виникає на тлі гострого респіраторного дистрес-синдрому [5 - 7], який розвивається у $25-42 \%$ пацієнтів із ГПП. Легеневі ускладнення та розвиток дихальної недостатності у пацієнтів із перитонітом значно погіршують прогноз захворювання, що в кінцевому підсумку призводить до високої смертності [8]. Провідними факторами патогенезу порушення аеро- 
гематичного бар'єру вважають підвищення в крові рівня токсичних сполук, у тому числі ендотоксину, розлади внутрішньоорганної гемодинаміки, тканинну гіпоксію, ацидоз, пошкодження системи легеневого сурфактанту [9]. Легеневі гемокапіляри - це перша ланка для медіаторів та ендотоксинів, а легені - перший орган на шляху їх детоксикації. Як наслідок, розвивається дисфункція сурфактантної системи, пов'язана з фосфоліпідним обміном та ушкодженням аерогематичного бар'єру [10]. Це пояснюється структурними і функціональними особливостями дихальної системи та прямою дією біологічних компонентів медіаторного каскаду на ії метаболічні функції, що сприяє змінам мікроциркуляторного русла. Водночас відбувається активація імунокомпетентних клітин, що супроводжується «респіраторним вибухом» і викидом великої кількості медіаторів запалення $[11,12]$. Внаслідок цього підвищується ендотеліальна проникність гемокапілярів легенів, порушуються їх респіраторні і нереспіраторні функції, а в подальшому розвиваються незворотні зміни гемодинаміки з прогресуванням гострого респіраторного дистрес-синдрому $[13,14]$.

Незважаючи на велику кількість літературних даних, питання морфологічних змін у легенях за наявності ГПП залишаються актуальними і потребують уточнення.

Мета дослідження: вивчити та оцінити морфологічні зміни в легенях тварин з експериментальним ГПП.

\section{Матеріали і методи дослідження}

В експерименті використані 32 білих щури, яких розподілили на дві групи: основну - 24 тварини із змодельованим перитонітом і контрольну - 8 інтактних тварин, яких утримували у стандартних умовах віварію. Обидві групи тварин репрезентативні за масою тіла, статтю та віком. Дане експериментальне дослідження проведено з дотри-

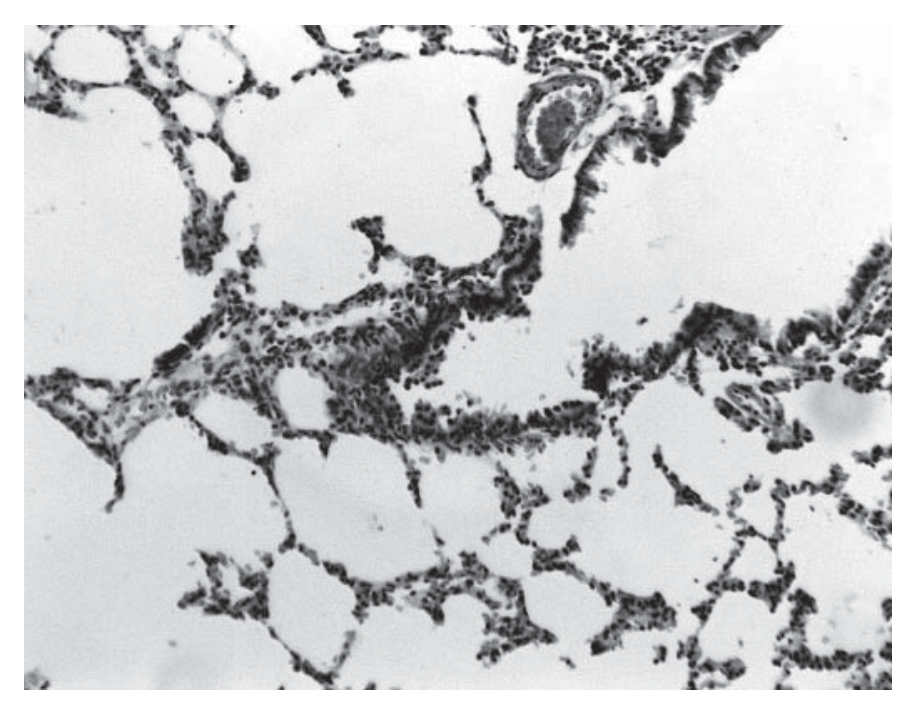

Puc. 1.

Мікрофото. Мікроскопічна організація легенів інтактних тварин. Структурний стан ацинусів, слабовиражена перибронхіальна лейкоцитарна інфільтрація. Забарвлення гематоксиліном та еозином. $\times 100$. манням загальних правил і положень Європейської конвенції із захисту хребетних тварин, які використовуються для дослідницьких та інших наукових цілей (Страсбург, 1986), Загальних етичних принципів експериментів на тваринах (Київ, 2001) та Закону України «Про захист тварин від жорстокого поводження» (2006).

Використали модель ГПП, запропоновану В. А. Лазаренком і співавторами [15], яка за етіологічними чинниками, клінічними проявами і фазністю перебігу захворювання близька до аналогічного процесу у людини. Калову суспензію отримували шляхом змішування ізотонічного розчину і калу зі сліпої кишки $2-3$ інтактних тварин, потім їі двічі фільтрували через подвійний шар марлі. Не пізніше ніж через 20 хв після приготування суспензію вводили щурам пункційним способом. Щоб не пошкодити внутрішні органи під час введення калової суспензії в черевну порожнину, тварин тримали вертикально, заднім кінцем тіла вгору. Методом пункції черевної стінки в центрі середньої лінії живота, направляючи кінець голки по черзі у праве і ліве підребер'я, праву і ліву клубові ділянки, вводили однакову кількість калової суспензії.

Матеріал для гістологічного дослідження вилучали на 1-шу, 3-тю та 7-му доби після виведення тварин з експерименту шляхом їх декапітації під тіопенталовим наркозом.

Для морфологічного дослідження легенів щурів з експериментальним перитонітом використовували метод світлової мікроскопії. Брали шматочки легеневої тканини товщиною не більше 0,5 cм, фіксували у 10\% розчині нейтрального формаліну. Після фіксації матеріал промивали, зневоднювали в розчинах спирту зростаючої концентрації, проводили через хлороформ та хлороформопарафінову суміш і заливали у парафінові блоки [16]. Зрізи товщиною 7 - 8 мкм виготовляли на санному мікротомі.

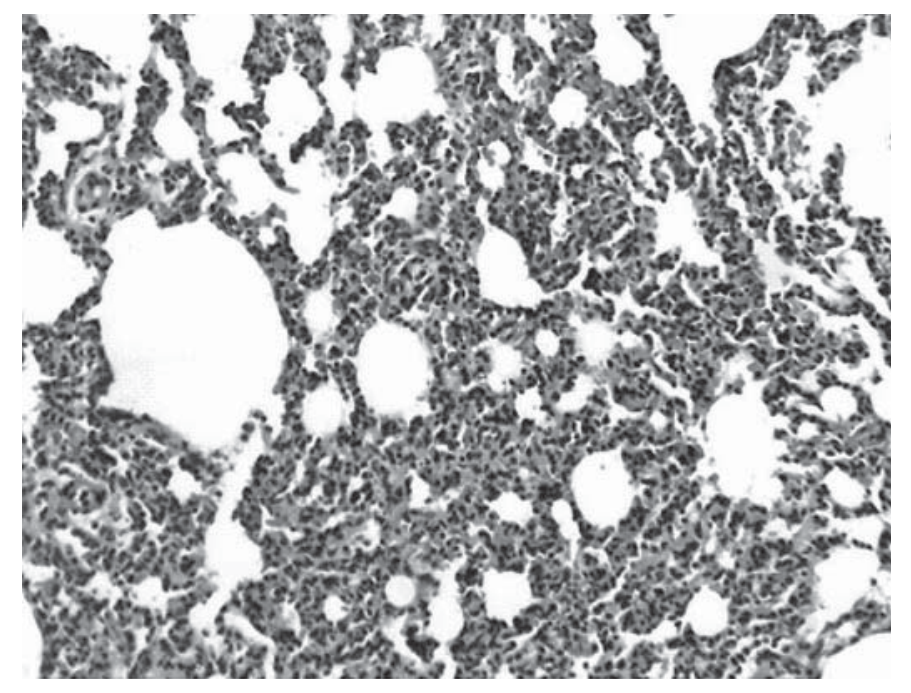

Puc. 2 .

Мікрофото. Мікроскопічні зміни легенів тварини на 1-шу добу після моделювання ГПП.

Потовщені міжальвеолярні перегородки, лейкоцитарна інфільтрація, явища дистелектазу.

Забарвлення гематоксиліном та еозином. $\times 100$. 


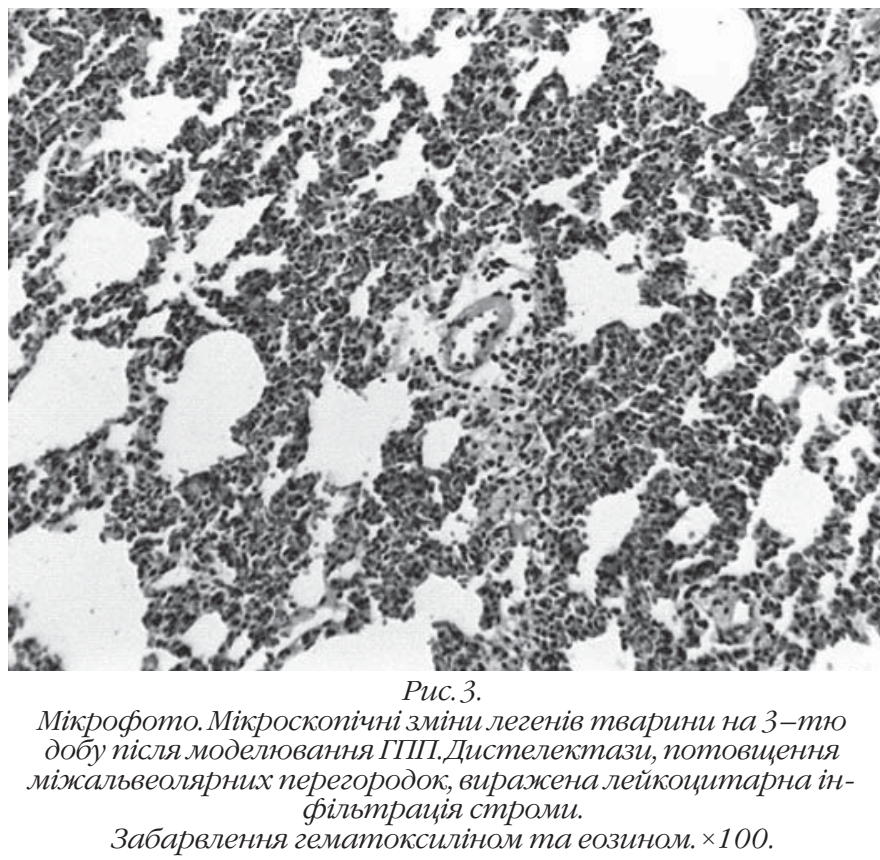

Мікропрепарати забарвлювали гематоксиліном та еозином, за Хартом та Ван-Гізоном і вивчали за допомогою світлового мікроскопа фірми «Olimpus». Фотозйомку мікропрепаратів здійснювали цифровою фотокамерою, поєднаною $з$ дікроскопом «C 3040-A DUP».

\section{Результати}

Мікроскопічне вивчення змін структурних компонентів легенів інтактних тварин (рис. 1) показало, що у них міжальвеолярні перегородки незначно потовщені за рахунок розширення та повнокров'я капілярів і формування дрібноклітинних інфільтратів; просвіти альвеол вільні від ексудату та клітинних елементів; судини великого і середнього калібру розширені із скупченнями еритроцитів, проте стінки їх мало змінені, периваскулярний набряк незначний; просвіти бронхів і бронхіол не розширені, війчастий епітелій, лімфоїдна тканина перибронхіальних ділянок не пошкоджені.

Дані мікроскопічного дослідження легенів щурів на 1-шу добу після моделювання ГПП значно відрізнялися від відповідних даних у інтактних тварин (рис. 2). Спостерігали розширення та повнокров'я судин середнього і дрібного калібру; ділянки спадання та емфізематозного розширення альвеол; посилення ексудативнозапальної реакції судин та периваскулярної клітинної інфільтрації, в окремих полях зору ще були явища дистелектазу; стінка бронхів потовщена, переважно за рахунок клітинних інфільтратів, просвіти бронхіол вільні від ексудату та клітинних елементів.

Мікроскопічним дослідженням легенів тварин на 3тю добу після моделювання ГПП виявили порушення в їх судинах та бронхах (рис.3). Більшість судин із широкими повнокровними просвітами; спостерігали еритродіапедез як у периваскулярні простори, так і в просвіт окремих альвеол; міжальвеолярні перегородки потовщені за

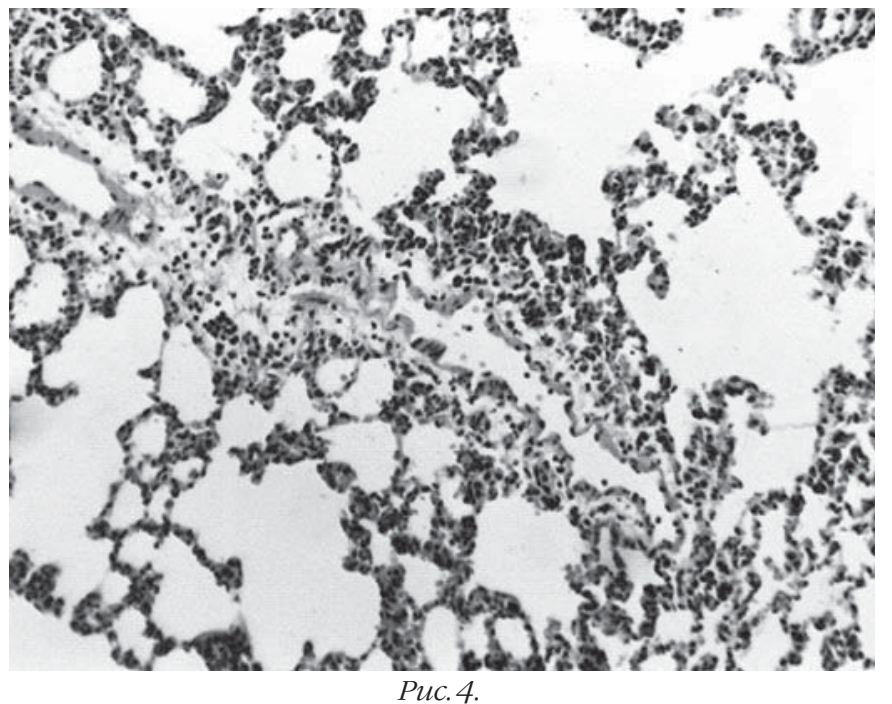

Мікрофото. Мікроскопічні зміни легенів тварини

на 7-му добу після моделювання ГПП. Стан структур респіраторного відділу легенів, помірна інфільтрація стромальної сполучної тканини.

Забарвлення гематоксиліном та еозином. $\times 100$.

рахунок набряку строми та лімфо- і гістіоцитарної інфільтрації; явища дистелектазу.

На 7-му добу після модельовання ГПП (рис.4) мікроскопічно в легенях тварин частина артерій і вен розширена і наповнена кров'ю, проте їх стінки краще структуровані; набряк адвентиції невеликий, помірний периваскулярний набряк; стінки бронхів помірно потовщені за рахунок набряку адвентиційної оболонки.

\section{Обговорення}

Морфологічні дослідження легеневої тканини в нашому експерименті показали, що наростання гіпоксії $є$ одним із провідних патогенетичних чинників у розвитку набряку легенів при ГПП. На користь цього свідчать виявлені нами такі зміни: повнокров'я судин, периваскулярні вогнищеві скупчення лімфоїдних клітин як у центральних, так і в периферичних відділах легенів, вогнищевий діапедез еритроцитів та їх вихід із порожнин альвеол і бронхів, дисателектаз. На 1-шу добу після моделювання ГПП у легенях спостерігали повнокров'я і набряк міжальвеолярних перегородок, у венах - крайове стояння лейкоцитів, у периферичних відділах легенів - вогнищеві крововиливи, схожі на геморагічний набряк, діапедез еритроцитів, у розширених лімфатичних судинах збільшення кількості малих лейкоцитів, дисателектаз. У периваскулярних відділах легенів виявили інтерстиційний набряк, нейтрофільну інфільтрацію. На 3-тю та 7-му доби експерименту виявлені зміни наростали, стінки бронхів були помірно потовщені за рахунок набряку адвентиційної оболонки. У респіраторному відділі спостерігали гетерогенні зміни альвеол, частина їх з розширеними просвітами, інші - невеликі. Міжальвеолярні перегородки мали помірну товщину.

Можна припустити, що внаслідок підвищеної проникності ендотелію легеневих мікросудин розвивається набряк легенів, що є характерною ознакою гострого дис- 
трес-синдрому, котрий починається з гострого ураження альвеолярно-капілярної мембрани як наслідку реакції легеневого ендотелію на системний запальний процес, спричинений ГПП.

\section{Висновки}

Під час гістологічного дослідження тканини легенів тварин із модельованим ГПП у порівнянні з інтактними щурами на 1-шу добу експерименту виявлено ділянки спадання та емфізематозного розширення альвеол, а також посилення ексудативно-запальної реакції судин та периваскулярної клітинної інфільтрації. Мікроскопічне дослідження легенів тварин на 3-ю добу після моделювання ГПП показало, що більшість судин мала широкі повнокровні просвіти, відбувався еритродіапедез як у периваскулярні простори, так і в просвіт окремих альвеол, міжальвеолярні перегородки були потовщеними за рахунок набряку строми та лімфо- і гістіоцитарної інфільтрації. На 7-му добу виявляли розширення вен і кровонаповення артерій, помірний периваскулярний набряк.

\section{Підтвердження}

Фінансування. Джерелом фінансування публікації статті $€$ кошти іï авторів.

Інформація про внесок кожного учасника. Дзюбановський І. Я. - ідея, концепція та дизайн дослідження; Вервега Б. М. - експериментальне моделювання гострого поширеного перитоніту, збір та опрацювання матеріалу, відбір тварин, формування експериментальних груп; Підручна С. Р. - проведення морфологічних досліджень, опрацювання результатів, формування висновків; Мельник Н. А. - оформлення статті, аналіз літературних джерел та отриманих результатів морфологічного дослідження, корекція та редагування матеріалу.

Конфлікт інтересів. Автори інформують про відсутність потенційного та явного конфлікту інтересів, пов'язаного з рукописом.

Згода на публікацію. Всі автори прочитали і схвалили остаточний варіант рукопису та дали згоду на його публікацію.

\section{References}

1. Bajaj JS, Tandon P, O’leary J, Wong F, Biggins S, Garcia-Tsao G, et al. Primary spontaneous bacterial peritonitis prophylaxis is associated with greater ICU admission and 30-day mortality compared to secondary spontaneous bacterial peritonitis prophylaxis. J Hepatol. 2018;68(Suppl 1):65-104. doi: 10.1016/S0168-8278(18)30353-2.

2. Enomoto H, Inoue Sh-i, Matsuhisa A, Nishiguchi Sh. Diagnosis of Spontaneous Bacterial Peritonitis and an In Situ Hybridization Approach to Detect an "Unidentified" Pathogen. [Internet]. Int J Hepatol. 2014;4:18. Available from: https:/www.hindawi.com/journals/ijh/2014/634617/ cta/ doi: 10.1155/2014/634617.

3. Yang SK, Xiao L, Zhang H, Xu XX, Song PA, Liu FY, Sun L. Diagnostic Accuracy of Serum Procalcitonin for Spontaneous Bacterial Peritonitis Due to End-stage Liver Disease: A Meta-analysis. BMC Infect Dis. 2014;14:452. doi: 10.1186/1471-2334-14-452.

4. Dzubanovsky IYa, Mignenko BO, Polyatsko KG. [Poliorhanna dysfunkciia u xvorykh na hostryi poshyrenyi perytonit]. Kharkivska khirurhichna shkola. 2007;4:70-3. [In Ukrainian].

5. Milić L, Grigorov I, Krstić S, Ćeranić MS, Jovanović B, Stevanović J, et al. Serum Level of HMGB1 Protein and Inflammatory Markers in Patients with Secondary Peritonitis: Time Course and the Association with Clinical Status. J. Med. Biochem. 2017;36(1):44-53. doi: 10.1515/ jomb-2016-0016.

6. Gerasymchuk MR, Zayats LM, Cherkasova VV. The role of endogenous intoxication and neutrophils in mechanisms of acute lung injury in case of experimental peritonitis. Vestnyk KazNMU. 2013;5:76-80. [In Ukrainian].

7. Gerasymchuk MR, Klishch IP, Varnava NYa. Place of endogenous intoxication at an early stage of development of the critical states of various etiologies. Inter-Medical. 2015;3(9):21-4.

8. Gerasymchuk MR, Zayacz LM, Cherkasova VV. Vplyv polietiolohichny`x eksperymentalnykh staniv na funkcionalnyi stan legen. Eksperymentalna i klinichna medycyna. 2016;(2):44-8. [In Ukrainian].

9. Mujahid S, Nielsen HC, Volpe MV. MiR-221 and miR-130a Regulate Lung Airway and Vascular Development. PLoS ONE. 2013;8(2):55-9. doi: 10.1371/journal.pone.0055911.

10. Karayama M, Inui N, Mori K, Kono M, Hozumi H, Suzuki Y, et al. Respiratory impedance is correlated with morphological changes in the lungs on three-dimensional CT in patients with COPD. Sci Rep. 2017;7:41709. doi: 10.1038/srep41709.

11. Ribeiro Júnior G, de Souza Xavier Costa N, Belotti L, Dos Santos Alemany AA, Amato-Lourenço LF, da Cunha PG, et al. Diesel exhaust exposure intensifies inflammatory and structural changes associated with lung aging in mice. Ecotoxicol Environ Saf. 2019;170:314-23. doi:10.1016/j.ecoenv.2018.11.139.

12. Hack CE, Gearhart JM. A rabbit lung morphology model for aerosol deposition and clearance. J Aerosol Science. 2016;99:144-56. doi:10.1016/j.jaerosci.2016.03.004.

13. Pidruchna SR. Dynamics of changes of the endogenous intoxication indices in the animals, suffering severe and combined trauma, after correction, using xenotransplants. Klin khir. 2013;(2):71-4. PMID: 23705489.

14. Pidruchna SR. Impact of xenoimplants on metabolic changes in the liver of rats in combined trauma. Klin khir. 2013;(3):59-62. PMID: 23718038.

15. Lazarenko VA, Lypatov VA, Blynkov YuYu, Skorykov DV. Eksperymentalnaia model rasprostranennoho kalovoho perytonyta. Chelovek y eho zdorove. 2008;4:128-32. [In Russian].

16. Logoyda L, Kondratova Y, Korobko D, Susla O, Soroka Yu, Tsytsiura R, et al. Youden's test of the chromatographic determination of captopril in pharmaceuticals. Int J Green Pharm. 2017;11(3):188-91. doi: 10.22377/ijgp.v11i03.1124.

Надійшла 16.06.19 